\title{
Penerapan Sistem Informasi Berbasis Website di Pondok Pesantren Kota Kediri
}

\author{
Ahmad Bagus Setiawan ${ }^{1}$, Juli Sulaksono ${ }^{2}$,Resty Wulanningrum ${ }^{3}$ \\ 1,2,3 Teknik Informatika, Fakultas Teknik, Universitas Nusantara PGRI Kediri

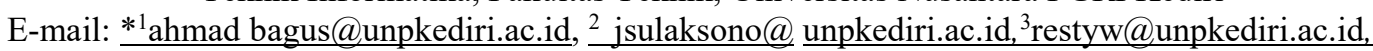

Abstrak - Pendataan santri di pondok pesantren menjadikan masalah yang utama bagi pengelola Pondok Pesantren. Dari data santri Diniyah, Tsanawiyah, dan Aliyah, begitu juga dalam pengelolaan keuangan, menjadikan pengelolaan untuk pembangunan Pondok Pesantren tidak berjalan dengan lancar, sistem pemdataan menggunakan buku induk merupakan dana utama yang sekarang masih di terapkan.

Dengan adanya Sistem Informasi berbasis website di Pondok Pesantren, pengurus pondok dapat mengetahui data Santri, rekap pembayaran, kurikulum dan data gedung yang dimiliki oleh pondok pesantren, hal ini berkaitan dengan pengembangan teknologi di pondok pesantren, untuk mewujudkan integrasi data santri.

Kata Kunci : Sistem Informasi, Pondok Pesantren, Website

Abstract - Data collection of santri in Islamic boarding schools makes it a major problem for the management of Islamic boarding schools. From the data of santri Diniyah, Tsanawiyah, and Aliyah, as well as in financial management, making management for the construction of Islamic Boarding Schools does not run smoothly, the system of using the master book is the main fund that is still being implemented.

With the existence of a website-based Information System in Islamic Boarding Schools, board administrators can find out Santri data, recapitulation, curriculum and building data owned by Islamic boarding schools, this is related to technology development in Islamic boarding schools, to realize santri data integration.

Kata Kunci - Information System, Islamic Boarding School, Website

\section{PENDAHULUAN}

Pondok pesantren merupakan tempat pendidikan berasaskan Agama Islam, dimana para santrinya di bawah bimbingan seorang ulama, yang lebih dikenal dengan kyai. Dimana pondok pesantren ini lahir ditengah-tengah masyarakat khususnya masyarakat islam. Didirikannya Pondok pesantren bertujuan untuk memberi pelajaran ilmu agama islam kepada parasantrinya supaya bisa menjadi bekal untuk dirinya baik di dunia maupun akherat, tidak sedikitpondok pesantren yang mencoba menyesuaikan diri akan suatu perubahan, namun ada juga pondokpesantren yang menutup diri dari pengaruh perkembangan teknologi saat ini.

Mengingat akan pesatnya kemajuan teknologi yang sudah merambah kesemua bidang, sertapola kehidupan masyarakat yang sudah relatif maju, dapat dipastikan hampir semua orang saat ini sudah memanfaatkan teknologi internet sebagai media penyampaian suatu informasi. Untuk mendapatkan informasi yang dibutuhkan, kita tidak perlu membuang waktu dan tenaga untuk datang ke tempat yang memiliki informasi tersebut, melainkan kita dapat memperoleh informasihanya dengan mengakses internet dari manapun dan kapanpun asalkan tersedia layanan internet. Dengan adanya internet masyarakat dapat bertukar informasi dengan mudah dan cepat, tanpa harus bertemu di suatu tempat hanya untuk menyampaikan suatu informasi.

Dengan pengamatan permasalah diatas, kami merencanakan untuk membuat "PENERAPAN SISTEM INFORMASI BERBASIS WEBSITE DI PONDOK PESANTREN KOTA KEDIRI" dimana 11ystem ini dapat secara langsung mengintegrasikan data santri pondok maupun santri madrasah 


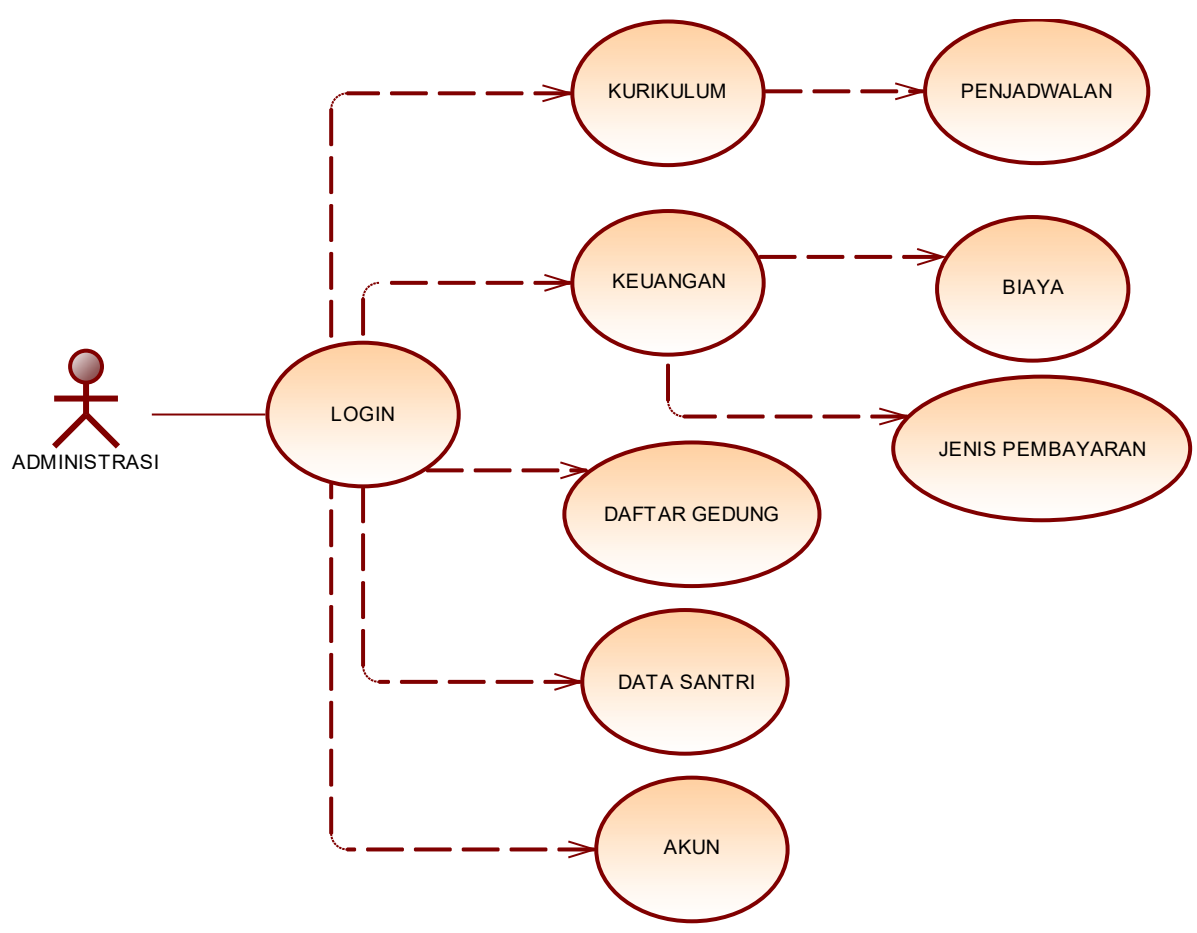

Gambar 1 Use case Sistem

Dalam gambaran sistem diatas digambarkan dalam sebuah sistem membutuhkan user dan password untuk bisa mengakses sistem informasi pondok pesantren, dimana administrator dapat menambahkan kurikulum, keuangan, daftar gedung, data santri dan akun. Sistem yang sudah terintegrasi ini di buat untuk memudahkan para pengguna pondok pesantren untuk melakukan pendataan data yang ada di pondok pesantren.

Telah diketahui bahwa informasi adalah sebuah bahan penting bagimanajemen. Sistem informasi dalam sebuah organisasi dibatasi oleh data yangdapat diperoleh, biaya untuk pengadaan, pengolahan dan penyimpanan dansebagainya. Sebuah sistem informasi berdasarkan komputer biasanya dapatmengurangi biaya sekaligus meningkatkan kemampuan dan prestasi sisteminformasi.

\section{a. Sistem Informasi}

Telah diketahui bahwa informasi adalah sebuah bahan penting bagi manajemen. Sistem informasi dalam sebuah organisasi dibatasi oleh data yang dapat diperoleh, biaya untuk pengadaan, pengolahan dan penyimpanan dan sebagainya. Sebuah sistem informasi berdasarkan komputer biasanya dapat mengurangi biaya sekaligus meningkatkan kemampuan dan prestasi sistem informasi. Menurut Jogiyanto H.M. [1]

Andri Kristanto, mendefinisikan sistem informasi merupakan kumpulan dari perangkat keras dan perangkat lunak komputer serta perangkat manusia yang akan mengolah data menggunakan perangkat keras dan perangkat lunak tersebut. [2]

Menurut Aji Supriyanto .Sistem informasi adalah sistem didalam suatu organisasi, yang mempertemukan kebutuhan pengolahan transaksi harian, mendukung operasi bersifat manajerial dan kegiatan strategi dari suatu organisasi dan menyediakan pihak luar tertentu dengan laporan-laporan yang diperlukan. [3]

Sistem Informasi Manajemen atau SIM adalah suatu sistem berbasis komputer yang membuat informasi tersedia bagi para pengguuna yang memiliki kebutuhan serupa. Menurut McLeod dan Schell. [4]

Dalam pendapat lain, M. Scott menjelaskan bahwa SIM ini adalah kumpulan sistem yang terkoordinasi dan bersifat rasional. Sistem tersebut bekerja untuk mengolah data menjadi sebuah informasi yang berharga.[5]

Selain itu sistem informasi dapat didefinisikan sebagai berikut :

1. Suatu sistem yang dibuat oleh manusia yang terdiri komponen- komponen dalam organisasi untuk mencapai suatu tujuan yaitu menyajikan informasi.

2. Sekumpulan prosedu rorganisasi yang pada saat dilaksanakanakan memberikan informasi bagi pengambil keputusan dan atau untuk mengendalikan organisasi. 
3. Suatu sistem dalam suatu organisasi yang mempertemukan kebutuhan pengolahan transaksi, mendukung operasi, bersifat manajerial dan kegiatan strategi dari suatu organisasi dan menyediakan pihak luar tertentu dengan laporan-laporan yang diperlukan.

\section{METODE PENELITIAN}

Metodologi penelitian adalah gambaran langkah-langkah yang di tempuh dalam menjalankan penelitian, Metode yang digunakan untuk pengembangan sistem yang akan dibuat adalah metode waterfall. Metode waterfall adalah sebuah metode pengembangan sistem atau software yang bersifat sekuensial linier yaitu proses pengerjaan dari suatu system dilakukan secara berurutan dan sistematis. Berikut ini merupakan tahapan - tahapan dari metode waterfall:

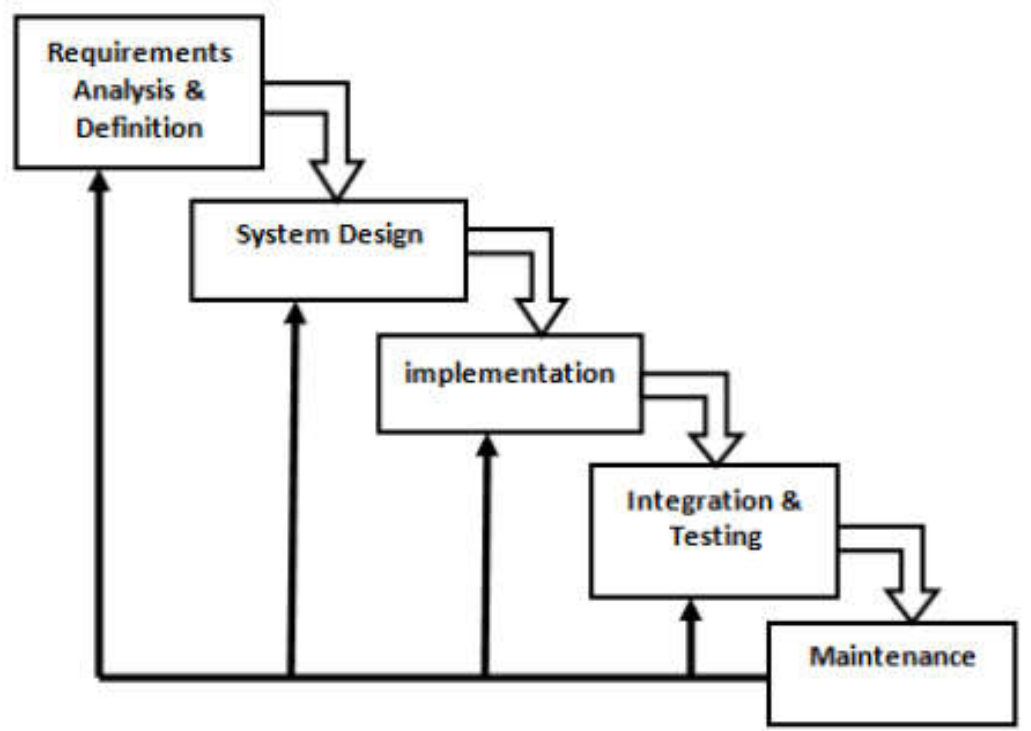

Gambar 1. Tahapan Dalam Model Waterfall

Secara garis besar metode waterfall mempunyai tahapan sebagai berikut ini :

1. AnalisadanDefinisiKebutuhan Requirement Analysis \& Definition

Pada tahap ini dilakukan analisa terhadap kebutuhan sistem baik software dan hardware. Dalam tahap ini juga dilakukan proses pengumpulan data dengan cara melakukan studi literatur, wawancara, observasi dan dokumentasi mengenai data - data santri yang diperlukan. Tahapan ini akan menghasilkan dokumen user requirement atau data yang berhubungan dengan keinginan user dalam pembuatan sistem. Dokumen ini yang akan menjadi acuan dalam tahap desain sistem.

\section{DesainSistem (System Design)}

Tahap desain sistem akan menerjemahkan syarat kebutuhan ke sebuah perancangan perangkat lunak sebelum dibuat coding. Pada proses ini dibuat perancangan arsitektur perangkat lunak, struktur data, representasi interface, dan algoritma prosedural.

\section{PembuatanSistem (Implementation)}

Pada tahap ini dilakukan penerjemahan dari proses desain kedalam bahasa yang bisa dikenali oleh komputer. Dalam proses ini dilakukan pembuatan program (coding) sesuai dengan sistem. Bahasa pemrograman yang digunakan dalam sistem ini adalah PHP, database yang digunakan untuk menyimpan data adalah MySQL. 


\section{IntegrasidanPengujianSistem(Integration \& Testing)}

Pada tahap ini dilakukan pengujian terhadap program yang telah dibuat dengan cara melakukan uji coba terhadap semua fungsi dan modul pada sistem.

\section{Pemeliharaan (Maintenance)}

Sistem yang telah dibuat dapat mengalami perubahan yang disebabkan kebutuhan perkembangan fungsional dari user atau disebabkan penyesuaian terhadap perkembangan lingkungan seperti harware, software, peripheral, atau sistem operasi baru.

\section{HASIL DAN PEMBAHASAN}

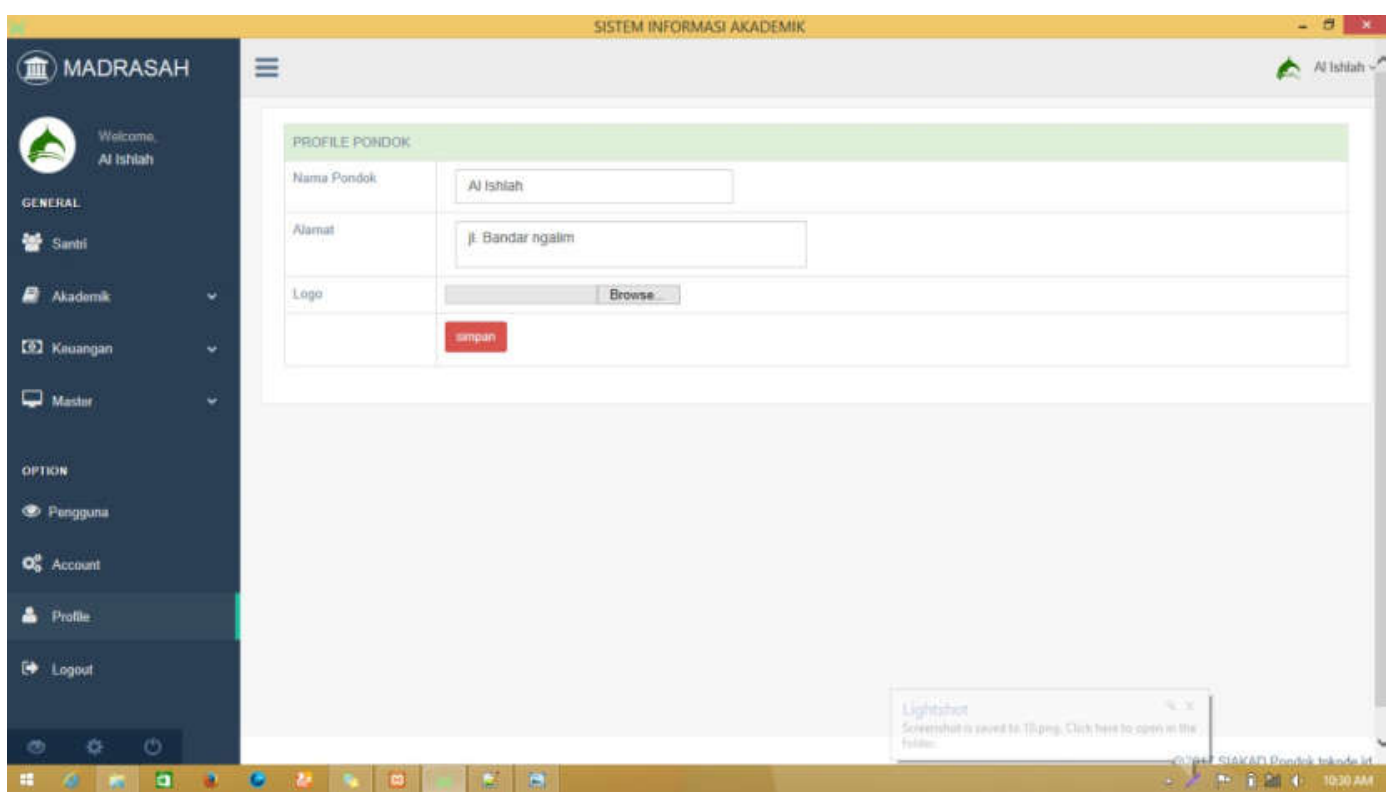

Gambar 3. Gambar Contens

Dalam Memberikan data nama pondok pesantren diberikan profil yang lengkap, untuk memudahkan identitas lokasi dan nama pondok pesantren. Dalam pengisian Profil dimungkinkan admin memberikan logo pondok pesantren. 


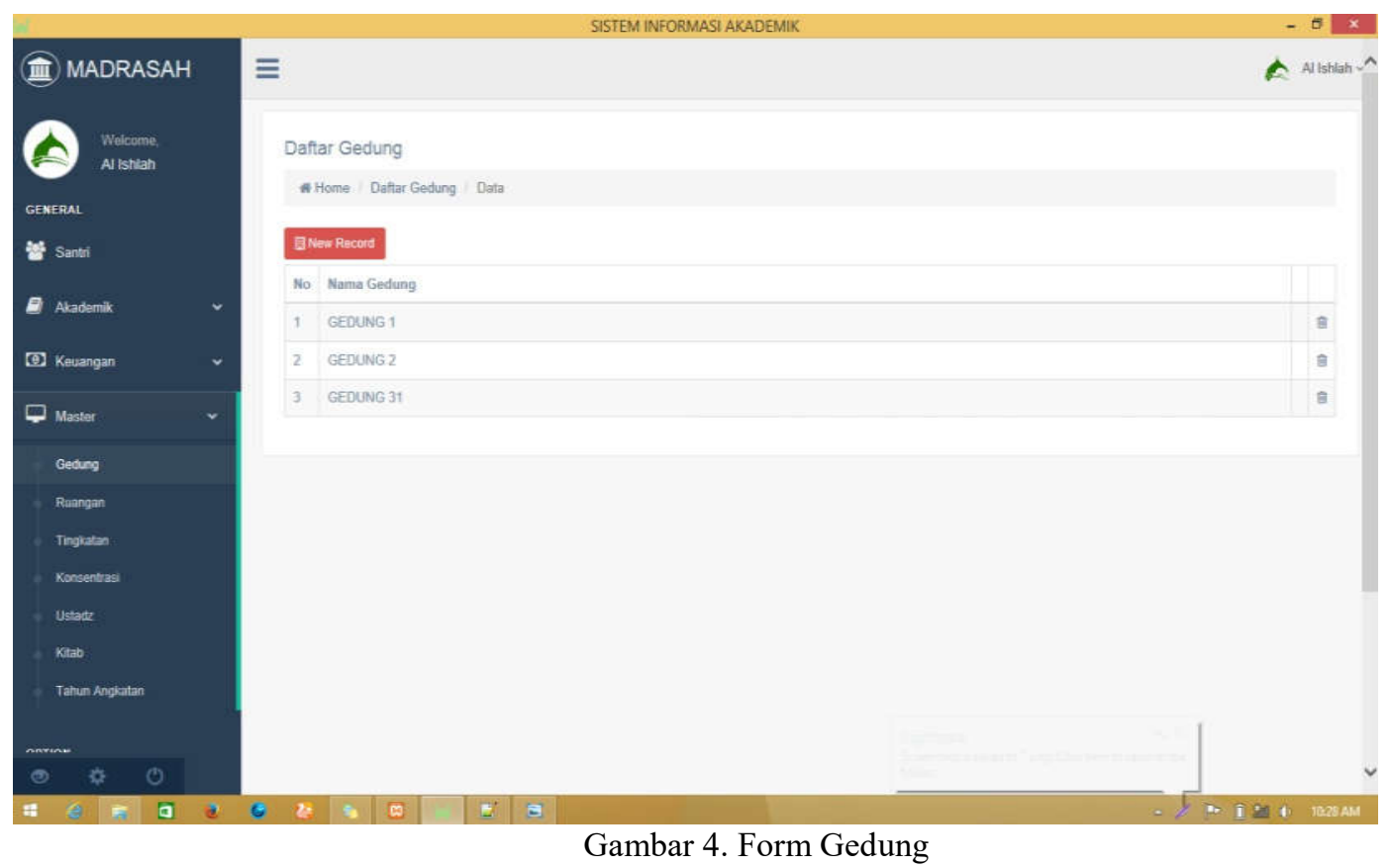

Dalam menu form Gudang disini menjelaskan tentang jumlah Ruangan dan gedung yang digunakan untuk Madrasah di pondok pesantren, form ini bertujuan untuk mempermudah dalam pemetaan kelas para santri yang akan mendapatkan pengajaran.

\section{SIMPULAN}

Dengan adanya Sistem Informasi berbasis website di Pondok Pesantren, pengurus pondok dapat mengetahui data Santri, rekap pembayaran, kurikulum dan data gedung yang dimiliki oleh pondok pesantren, hal ini berkaitan dengan pengembangan teknologi di pondok pesantren, untuk mewujudkan integrasi data santri.

\section{SARAN}

Untuk Sistem Selanjutnya bisa dikembangkan dengan sistem Mobile, agar memudahkan anggota dalam mengakses informasi dan, calon anggota baru melakukan pendaftaran anggota Asosiasi

\section{DAFTAR PUSTAKA}

[1] Jogiyanto, HM, Analisis dan Desain Sistem Informasi : Pendekatan Terstruktur Teori dan Praktek Aplikasi Bisnis, Yogyakarta : Andi, 2005

[2] Andri Kristanto, 2008. Perancangan Sistem Informasi. Gava Media.Yogyakarta

[3] Aji Supriyanto. 2005. "Pengantar Teknologi Informasi". Edisi Pertama. Penerbit Salemba Empat. Jakarta.

[4] McLeod, Jr., Raymond; Schell, George P. 2011. Sistem Informasi Managemen (Terjemahan). Jakarta: Salemba Empat

[5] Scott, George M. 2004. Prinsip-prinsip Sistem Informasi Manajemen (Terjemahan). Jakarta: PT Raja Grafindo Persada

[6] Setiawan, Ahmad bagus. 2018 Sistem Informasi Pendaftaran Online Anggota Asosiasi Program Studi Informatika Pgri Jawa Timur, Jurnal Joutica UNISLA Lamongan 